\title{
Universities as knowledge producers for economic development: how is Brazil allocating resources in the production of new relevant knowledge for innovation?†
}

Tulio Chiarini* Karina Pereira Vieira**

\begin{abstract}
Universities have broadly similar functions in the innovation systems of most industrial and industrializing countries; however the relevance of their role alters substantially. In Brazil, universities are the most important knowledge producers. Departing from the evidence that they do not form a homogeneous group (which is corroborated using the T-Theil index of inequality), a possible classification is then suggested: 'leader universities', 'threshold universities' and 'unveiling universities,' which are in turn divided into two different subclasses: 'catching-up universities' and 'embryonic universities'. This paper demonstrates that even though the largest allocation on financial resources goes to 'hard sciences', there is a large allocation of human resources within humanities, applied social sciences and linguistics, arts and literature (soft sciences). This distortion in the distribution of researchers with a relative high concentration in humanities and applied social science may directly affect the countries innovation capacity. Brazil may not be producing the quantity of pertinent human resources expected to compete in the world's technological advanced markets.
\end{abstract}

Key-words: Universities; Knowledge Production; Innovation System.

JEL code: O33; I23; I28.

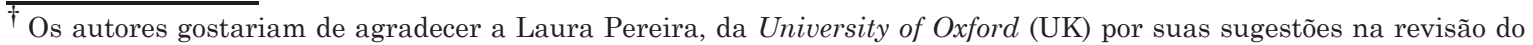
manuscrito. Todos os erros restantes são dos autores'.

*Mestre em Economia pela Universidade Federal do Rio Grande do Sul (UFRGS). Doutorando em Economia pela Universidade Estadual de Campinas (UNICAMP) e professor de Economia na Universidade Federal de Itajubá (UNIFEI). Endereço eletrônico: tuliochiarini@unifei.edu.br

** Mestre em Economia pela Universidade Federal de Minas Gerais. Analista sócio-econômico do Instituto Basileiro de Geografia e Estatística. Endereço eletrônico: karina.pvieira@gmail.com_
} 


\author{
Policies for science and technology \\ must always be a mixture of realism and idealism. \\ Chris Freeman (1921-2010)
}

\title{
1 Introduction
}

This paper starts from the idea that knowledge has become a competitive factor and a sine qua non component for innovative and development capacity, both regionally and nationally. Social, political, cultural and institutional characteristics have an active role in shaping an innovative environment and there are many agents that should be taken into consideration, beyond their potentially tangled relationships, for an effective pro-development policy.

One of these agents is the university, understood here as an institution whose social role goes beyond simply forming a more 'enlightened' society, but to produce scientific and technological knowledge. Universities are then understood as knowledge producers responsible for fostering economic development.

Although universities meet broadly similar functions in the innovation systems of most industrial and industrializing countries, the relevance of their role varies considerably. Furthermore, knowledge production does not have the same intensity in every economy. This variability is influenced, for instance, by the structure of domestic industries, the size and structure of other publicly funded research performers, and numerous other factors (Mowery; Sampat, 2005). In Latin American economies, for example, the incentive regime for research is misaligned; there is little expectation that publicly generated knowledge will be transferred for commercial application in order to realize productivity gains and expenditure is also not geared toward cost-effective, output-oriented research (Rodrígues et al., 2008). Despite existing efforts in making a more comprehensive research system, there is still a gap between scientific production and the amount of technological innovation in those countries and this is a peculiar feature of the region's development process. Unfortunately, Brazil is no exception.

Studying universities may then shed new light in the interpretation of the National System of Innovation. The objective of this paper is to describe the main features of the most important knowledge producers in Brazil, namely the universities. It will be shown that despite the great effort in allocating financial resources for research in specific areas that fit the priority industrial sectors and scientific and technological policies of the country, there is a misaligned allocation of human resources in other fields that are not engineering-intensive.

The paper is structured around three sections: the first presents a synthesis of universities' role for economic development which will serve as a reference throughout the paper. Section 2 succinctly underlines that even though the Brazilian tertiary education system is relatively recent, it has been growing rapidly. It will be also shown that the title of "new emergent scientific 
nation' granted to the country does not mean it has overcome structural problems usually attributed to Latin American economies.

There is a lack of synchronization between the incentive regimes of science and technology policies that on the one hand define areas that are important for playing technological and economical catch-up and on the other hand do not have a well-defined policy to allocate human resources to those areas. Section 2 also identifies that not all universities in Brazil are committed to research as this is a role normally attributed to the public ones. Thus the focus of analysis is on the federally funded universities plus the three state funded universities of São Paulo State. The analysis will involve numerous detours into the role of universities to support innovation for the country's development.

Departing from the evidence that those universities do not form a homogeneous group (which is corroborated using the T-Theil index of inequality), a possible classification is then suggested in section 3: 'leader universities', 'threshold universities' and 'unveiling universities' which are then divided into two subclasses: 'catching-up universities' and 'embryonic universities'. This is a first attempt classification which is an original contribution made by this study that may encourage fresh discussions.

Our hypothesis is that Brazil is not appropriately allocating resources to produce new techno-scientific knowledge with which to compete in the world's technological advanced markets and to act on 'windows of opportunities.' It may therefore not be ready to enter an internationally competitive environment. The results presented in section 3 show that despite the financial resources allocated in strategic fields of knowledge, there is a large allocation of human resources (researchers) within humanities, applied social sciences and linguistics, arts and literature (soft sciences) and that most of the students enrolled in post-graduate programs in the Brazilian Higher Education Institutions (HEIs) are in the same fields of knowledge. This means that in the coming years the country will put in the market work force about two times more Masters/Doctors specializing in 'soft sciences' than in engineering. The importance of the latter is obvious for scientific research and technological innovation as science and technology research are as close to industry and markets as never before (Schwartzman et al., 1995). policies.

Finally this papers ends with some final considerations for public

\section{Universities' role for economic development}

Countries' innovation efforts are not homogeneous. Some, especially those in the Global North, have shown greater innovation efforts in research and development (R\&D) over the past decades when compared to those in the Global South. The importance of R\&D lies in the fact that it is a driver for the process of both knowledge and technological accumulation enabling development from what was called 'windows of opportunities' (Perez, 2001). Thus, chances for development depend on each of the opportunity achievements made in previous 
phases, indicating the path dependency of the development process. These achievements should reflect a sound understanding of the technological paradigm, the new knowledge and ability to absorb/produce new technologies, and the existence of available infrastructure.

The new knowledge and technologies production reflects the importance of investment in R\&D, education and training, which are considered essential for capital accumulation, economic growth, technological know-how and socioeconomic development. However, investment in human capital is not the single solution for development per se. In a knowledge-based economy, not only is the creation of knowledge relevant, but also the creation of relevant knowledge.

In Latin American countries, the main locus of knowledge production is the university (Arocena; Sutz, 2001). Eight different functions (or outputs) of modern research universities that may lead to economic development impacts can be identified: creation of knowledge, human-capital creation, transfer of existing know-how, technological innovation, capital investment, regional leadership, knowledge infrastructure production and influence on the regional milieu. Each one of the outputs mentioned may cause a different pattern of effects on the economy, ranging from the direct and indirect effects of university spending to productivity gains in private companies, from the creation of spinoff enterprises, and the capacity to sustain long-term development and growth (Goldstein; Drucker, 2007).

In other words, universities play an important role in the process of creating and disseminating new scientific knowledge and new technologies through basic research, applied research, development and engineering. They also have the role of supplying skilled labor to meet the demand of the productive sector. Within universities, research staff are renewed and knowledge is updated (Marcovitch, 1999).

Moreover, universitiescanbe seen as strategicagentsfor 'catching-up'once they contribute to the scientific and technological development of the country. These are the major drivers able to ensure innovation and lead to economic and social changes. Scientific-technological development is a dynamic process and is the result of a collective interaction among different economic agents, especially since the new technological paradigms are permeated by a scientific knowledge which is close to the knowledge frontier; hence it is strategic to promote an active role of the universities and to tighten the university-industrygovernment network.

The symbiosis between these three agents, was accounted by Sabato and Botana (1968) and gained new prominence with the 'triple helix' approach (Leydesdorff; Etzkiwitz, 1998; Leydesdorff, 2000; Etzkiwitz et al., 2000; Etzkiwitz, 2003; Leydesdorff; Meyer, 2006; Leydesdorff, 2010) which recognizes that these actors can play the role of each other, so that the innovative system works properly, complementing the framework proposed by the Innovation System (IS). 


\section{Brasilian university system}

The Brazilian university system is relatively recent and it has been in existence for less than a century (Mello et al., 2009; Maculan; Mello, 2009). Compared to other Latin American countries, Brazil started relatively late on establishing universities (Suzigan; Albuquerque, 2009). While in some Latin American countries the first universities were established in the $16^{\text {th }}$ century (as in Mexico and Peru) or in the $17^{\text {th }}$ century (as in Bolivia), in Brazil colleges of medicine, law or engineering emerged only in the first half of the $19^{\text {th }}$ century (Mello et al., 2009) and the first university was established solely in 1920, in Rio de Janeiro by the Federal Government. It was 1934 before the state of São Paulo created its own university (Maculan; Mello, 2009), namely São Paulo University (USP), which was Brazil' first fully-fledged university (Schwartzman, 1979).

It is clear that the Brazilian university system had a late development and the history of the country's economy and society had a long-lasting influence, which is embedded in Brazilian higher education institutions' (HEIs) features: small in scale, concentration in humanities and applied social science, weak links to production activities, and applied research circumscribed to some fields such as agronomy, mining/metallurgy, and health sciences. Engineering fields germinated even later in Brazil, and graduate courses linking teaching and research activities were ushered in only in the 1960s, nurtured by federal government (Suzigan; Albuquerque, 2009).

Examining the number of scientific and engineering articles published in some particular fields, that is to say, physics, biology, chemistry, mathematics, clinical medicine, biomedical research, engineering and technology, and earth and space sciences, Brazil is ranked 15th in the world, contributing $1.59 \%$ of all those articles issued (Figure 1) which demonstrates the modest performance of the country vis-à-vis the research done in more industrialized countries.

Figure 1 - Scientific and technical journal articles per selected country, \%, 2007.

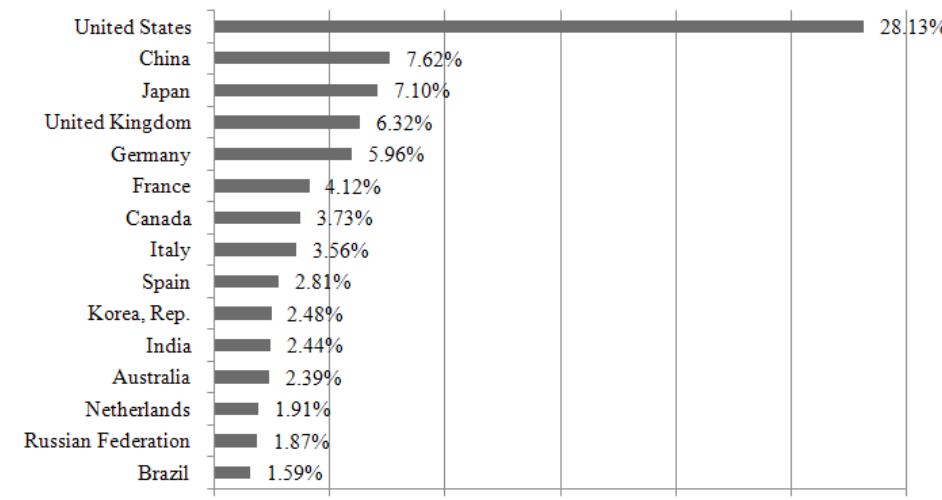

Source: Authors' own. Data sourced from the World Bank Data Catalog. Note: Scientific and technical journal articles refer to the number of scientific and engineering articles published in the following fields: physics, biology, chemistry, mathematics, clinical medicine, biomedical research, engineering and technology, and earth and space sciences. 
Even with this modest performance and considering that Brazil has an immature Innovation System (Albuquerque et al., 2005; Suzigan; Albuquerque, 2008) once characterized by weak links between scientific infra-structure and technological activities (Albuquerque, 2004), science activities in the country are striking with investment and scientific productivity outperforming general trends of growth making the country a new emergent scientific nation (RS, 2011). Nonetheless, the question that should be addressed is: what are the main institutions responsible for science activities and knowledge production in Brazil? Private HEIs are specialized in the teaching mission and those that are dedicated to research are rare exceptions in the country, thus the great amount of scientific knowledge production is accredited mostly to public HEIs (Chiarini; Vieira, in press), more precisely federally funded universities.

A particularity of the Brazilian university system is that most private HEIs seem to be specialized in teaching and in some well-defined fields of knowledge (such as management, law, human sciences), with their research activities being almost entirely residual (Maculan; Mello, 2009). This is corroborated by taking into account the number of articles ${ }^{1}$ published in national and international journal: Brazilian federally funded universities contribute to $45 \%$ of total article publications, in 2008 , and if we sum up to this percentage the publications of the three São Paulo state funded universities - State University of Campinas (UNICAMP), State University of São Paulo (USP) and Paulista State University (UNESP) - the total percentage reaches nearly $66 \%$.

According to the Brazilian Ministry of Education and Culture (MEC) in 2009 there were 186 Brazilian universities of which approximately 53\% were public (federally, state or municipal funded) and about $47 \%$ were private. Nevertheless, if all HEIs (universities, university centers and colleges) are considered, there were 2,314 institutions of which only about $10 \%$ were public (Table 1). In 2010 three more federal universities were legitimized and established, accounting for a total of 58 federally funded universities, which are unequally distributed throughout the Brazilian territory (Table 2). 33\% of those universities are concentrated in the Southeast region while only $9 \%$ are in the Central-west region. The former region has 4.75 federally funded universities per state whereas the latter has 1.25 .

Table 1-Total Brazilian HEIs and Universities, 2009.

\begin{tabular}{lrrrrr}
\hline & HEIs & Universities & HEIs & Universitie \\
\cline { 3 - 5 } & Total & Total & $\%$ & $\%$ \\
\hline Brazil & 2,314 & 186 & 100 & 100 \\
Public & 245 & 100 & 10.59 & 53.76 \\
Federal & 94 & 55 & 4.06 & 29.57 \\
State & 84 & 38 & 3.63 & 20.43 \\
Municipal & 67 & 7 & 2.90 & 3.76 \\
Private & 2,069 & 86 & 89.41 & 46.24 \\
North & 147 & 14 & 6.35 & 7.53 \\
Northeast & 448 & 35 & 19.36 & 18.82 \\
Southeast & 1,090 & 80 & 47.10 & 43.01 \\
South & 386 & 43 & 16.68 & 23.12 \\
\hline rce: Authors' own. Data sourced from Brazilian Ministry of Education.
\end{tabular}

1 Here we are considering all fields of knowledge, not only the scientific and engineering articles as the data available by the World Bank. 
Table 2 -Total Federally funded Universities, Percentage of Federally funded University per region, and Federally funded University per state, Brazil, 2010.

\begin{tabular}{l|r|r|c}
\hline \multirow{2}{*}{\multicolumn{1}{c|}{ Brazil (26 States and a F.D.) }} & Total & \multirow{2}{*}{$\%$} & $\begin{array}{c}\text { Federal Public per State } \\
\text { No) }\end{array}$ \\
\cline { 2 - 4 } & 58 & 100 & 2.14 \\
\hline Southeast Region (4 States) & 19 & 33 & 4.75 \\
Northeast Region (9 States) & 15 & 26 & 1.66 \\
South Region (3 States) & 11 & 19 & 3.66 \\
North Region (7 States) & 8 & 14 & 1.14 \\
Central-west Region (3 States and a F.D.) & 5 & 9 & 1.25 \\
\hline
\end{tabular}

Source: Authors' own. Data sourced from Brazilian Ministry of Education. (*) Brazil is currently divided into five regions by the Brazilian Institute of Geography and Statistics (IBGE) and into 26 States and a Federal District (F.D.). For simplification we considered 27 States.

It is worth mentioning that the title of new emergent scientific nation (RS, 2011) granted to Brazil does not mean it has overcome structural problems associated with Latin American countries, such as illiteracy. One crucial difficulty faced by those countries is to raise the number of undergraduate students, especially in some specific areas as engineering. In 2008, for instance, there were 5,958 millions of enrolments in Brazilian tertiary education compared to the 18,248 million in the USA or 3,939 million and 3,204 million in Japan and Republic of Korea (much smaller than Brazil) respectively ${ }^{2}$.

\section{Knowledge production in federal universities}

In order to describe Brazilian HEIs, this section starts by measuring the degree of inequality among federally funded universities. This measure is important as a starting point to characterize these institutions in Brazil and will shed new light on the interpretation of the Brazilian National System of Innovation and how they are capable of supporting the country's development. The choice to analyze only some HEIs in Brazil- the federally funded universities- is due to the fact that they are not only engaged in teaching, but also in research activities and in commercializing the results of their research activities (Maculan; Mello, 2009; Chiarini; Vieira, in press). Therefore, the following analysis will consider 55 federally funded universities (excluding three universities $^{3}$ legally established only in 2010 as they do not have any observable and comparable data because the analysis here is based on 2008 data).

\subsection{T-Theil index as a measure of Brazilian university inequalities}

From an index capable of measuring inequalities in a statistical distribution, we can quantify how unequal the Brazilian federally funded universities are, regarding their researchers, research groups, their bibliographic production and their technical production.

2 Global Education Digest 2010, from Unesco.

3 Universidade Federal da Fronteira Sul (UFFS), Universidade da Integração Internacional da Lusofonia AfroBrasileira (UNILAB) and Universidade Federal da Integração Latino-Americana (UNILA). 
Albuquerque et al. (2001) calculated the Gini coefficient of inequality for scientific and technology production for Brazilian municipalities in 2000 coming to a value of 0.9873 for production technology (proxy patents), 0.9958 for scientific production (proxy articles) and 0.9937 for researchers, which shows that the spatial distribution of innovative activities in Brazil is highly concentrated. Our objective is therefore aligned to the work of Albuquerque et al. (2001), but is distinguished by its method.

Unlike Albuquerque et al. (2001), we used the Theil-T inequality index for measuring inequality, which can be mathematically deduced by assuming a population with $n$ elements where each element has a non-negative fraction of a given variable, say $Y\left(Y_{i} \geq o\right.$, with $\left.i=1, \ldots, n\right)$ : if the distribution mean of $Y$ is $\mu$ and $X_{i}$ is the value of the $i$-th element, $Y_{i}=\frac{X_{i}}{n \mu}$ and, therefore, $\sum_{i=1}^{n} Y_{i}=1$.

Considering that $H(Y)$ is defined as the entropy of the distribution, we have $H(Y)=\sum_{i=1}^{n} Y_{i} \log \frac{1}{Y_{i}}$, which can range from $0 \leq H(Y) \leq \log (n)$. If $H(Y)=0$, there is perfect inequility, ${ }^{i}$ and on the contrary if $H(Y)=\log (n)$, there is perfect equality. The Theil-T inequality index is the maximum possible entropy of the data minus the observed entropy and it is the same as redundancy in information theory (Theil, 1967 apud Hoffmann, 2006), as it follows:

$$
\begin{aligned}
T & =\log (n)-H(Y) \\
T & =\sum_{i=1}^{n} Y_{i} \log (n) Y_{i} \\
T & =\sum_{i=1}^{n} Y_{i} \log \frac{Y_{i}}{1 / n}
\end{aligned}
$$

Thus for the variable of Brazilian research groups, we have the following analysis. The population is comprised of 55 members, $n$, (all federally funded universities of Brazil, not considering the UFFS, UNILA and UNILAB because there is no observable data, since they were legally established only in 2010). Each member has a fraction of the total number of research groups $\left(Y_{i} ; Y\right.$ í $)$. The average number of research groups is given by $\mu$ and $X_{i}$ is the volume of research groups in the $i$-th institution.

So we calculate the Theil-T inequality index for the year 2008. The closer to 0 , the more perfect the inequality among the considered universities and the closer to 1.74036 , which is exactly the $\log (5)$ value, the more equal are the universities. The same is done for the other items, as shown in Table 3.

Based on the information displayed in Table 3, we can infer that the federally funded universities in Brazil do not make a homogenous group, as there is a high degree of inequality in all these four variables presented. The highest inequality occurs when considering technical production. If we considered three more universities, which were excluded due to not being federally funded, but which are significant in the Brazilian National Innovation System (USP, UNESP and UNICAMP) as suggested on section 2, then we get following results. 
Table 3 - Theil-T inequality index of researchers, research groups, bibliographic production and technical production of the Federally funded Universities of Brazil, 2008 .

\begin{tabular}{ccccc}
\hline Researchers & $\begin{array}{c}\text { Research } \\
\text { Groups }\end{array}$ & $\begin{array}{c}\text { Publication } \\
\text { of research } \\
\text { articles }(*)\end{array}$ & $\begin{array}{c}\text { Technical } \\
\text { Production(**) }\end{array}$ \\
\hline Theil-T & 0.163764 & 0.191423 & 0.216472 & 0.34456 \\
\hline
\end{tabular}

Source: Authors' own. Data sourced from the Directory of Research Groups of the National Council for Scientific and Technological Development (CNPq). $\left(^{*}\right)$ Articles published in nationally and internationally indexed journals; $(* *)$ Technical Production here refers to the sum of the production of software and technology products which had patent registration.

The population now is comprised of 58 members, $n$, (all federally funded universities of Brazil, not considering again the UFFS, UNILA and UNILAB, but this time including UNICAMP, USP and UNESP). Once again each member has a fraction of the total number of research groups $\left(Y_{i}\right.$ iY 0 ). The average number of research groups is given by $\mu$ and $X_{i}$ is the volume of research groups in the $i$-th institution. Once more we calculate the Theil-T inequality index for the year 2008. The closer to 0, more greater the inequality among the considered universities and the closer to $1.763428,(\log (8))$, the more equal the universities are (Table 4).

Table 4 - Theil-T inequality index of researchers, research groups, bibliographic productionand technical production of the Federally funded Universities of Brazil and theState funded Universities of São Paulo State, 2008

\begin{tabular}{lcccc}
\hline Researchers & $\begin{array}{c}\text { Research } \\
\text { Groups }\end{array}$ & $\begin{array}{c}\text { Publication } \\
\text { of research } \\
\text { articles (*) }\end{array}$ & $\begin{array}{c}\text { Technical } \\
\text { Production(**) }\end{array}$ \\
\hline Theil-T & 0.229384 & 0.23291 & 0.315712 & 0.38172 \\
\hline
\end{tabular}

Source: Authors' own. Data sourced from the Directory of Research Groups of the National Council for Scientific and Technological Development (CNPq). $\left(^{*}\right)$ Articles published in nationally and internationally indexed journals; $(* *)$ Technical Production here refers to the sum of the production of software and technology products which had patent registration.

We find now a higher degree of inequality and again the biggest inequality happens when considering the technical production. This justifies once again the reason why the three São Paulo state funded universities must be included in the analysis even though they are not federally funded ones. After demonstrating the inequality among those institutions in Brazil, we ask whether there is any correlation between bibliographic production and the number of researchers and/or research groups. Our analysis shows that there is a high correlation: see Figures 2 and 3 below. 
Figure 2 - Correlation between Researchers and Publication of research articles

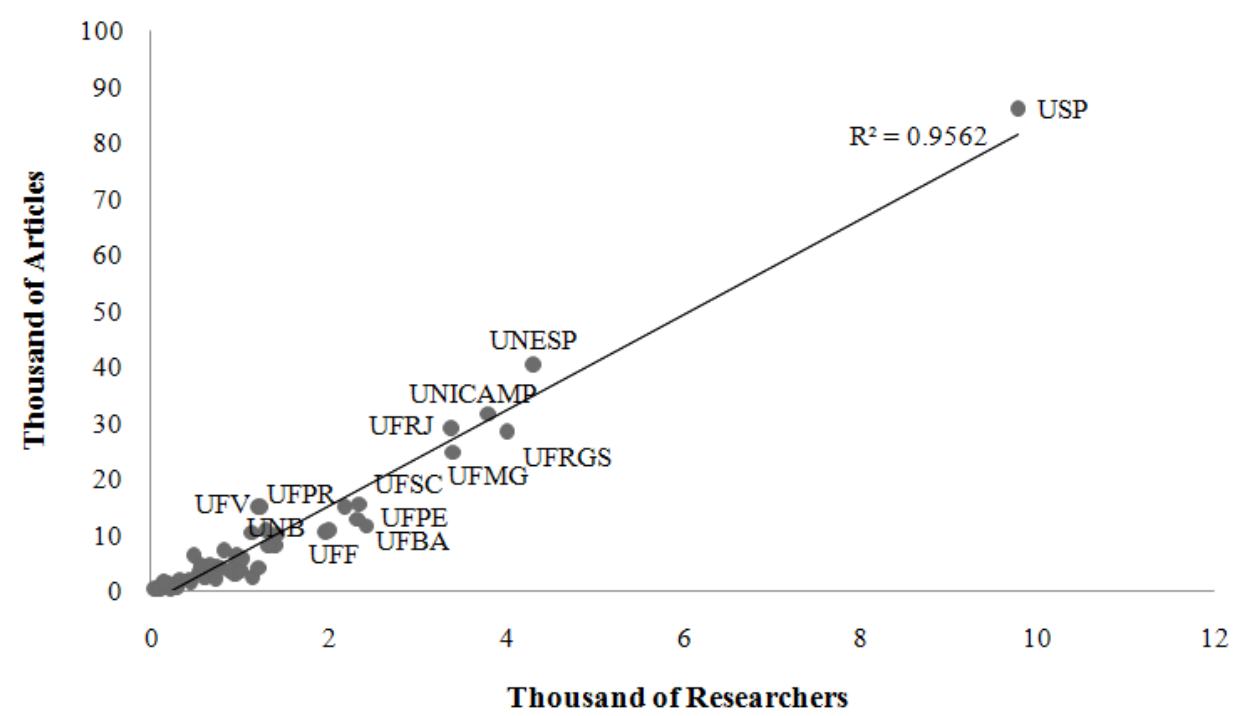

Source: Authors' own. Data sourced from the Directory of Research Groups of the National Council for Scientific and Technological Development (CNPq). Note: Articles published in nationally and internationally indexed journals.

Figure 3 - Correlation between Researchers and technical production

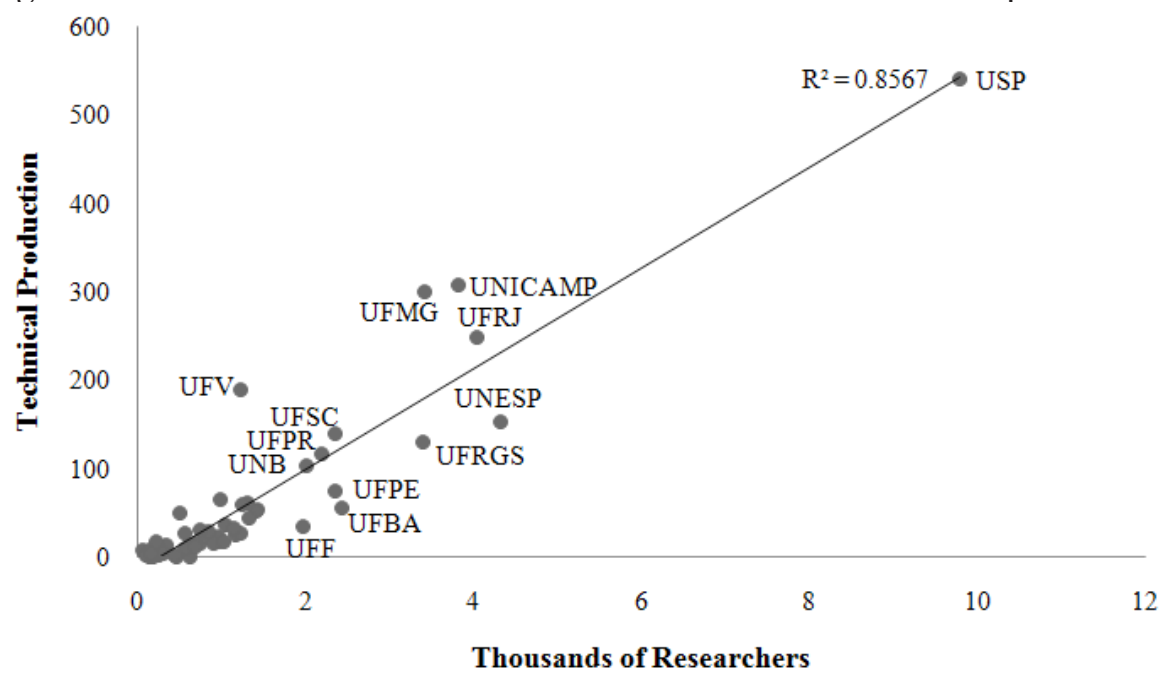

Source: Authors' own. Data sourced from the Directory of Research Groups of the National Council for Scientific and Technological Development $(\mathrm{CNPq})$. Note: Technical Production refers to the sum of the production of software and technology products which had patent registration.

As it is shown in figure 2, there is a relationship between researchers and the total amount of articles published (correlation coefficient is 0.97784) and three classifications can be identified: 'leader universities' (formed only by USP), 'threshold universities' (constituted by UNESP, UNICAMP,UFRJ, UFRGS and UFMG) and the 'unveiling universities' which are clearly divided into two different subclasses: 'catching-up universities' (UFPE, UFSC, UFBA, 
UFF, UFPR and UNB) and 'embryonic universities' (the rest). Figure 3 shows there is a link between researchers and total amount of technical production and the same classification of universities may be identified (correlation coefficient is 0.92521 ).

Now we analyze the different features of those institutions considering that they are unequal and they are classified into three types (leader universities', 'threshold universities' and 'unveiling universities') and then understand their role in shaping the Brazilian System of Innovation.

\subsection{Fields of knowledge in the Brazilian HEIs}

By fields of knowledge we refer to the subject areas or disciplines into which knowledge is frequently classified according to the categories proposed by the Coordination of Improvement of Higher Education Personnel (CAPES), which is a Foundation within the Ministry of Education and Culture in Brazil. The following large areas are identified: agricultural science; biological sciences; exact and earth sciences; health sciences; humanities; applied social sciences; engineering; and linguistics, arts and literature.

Analyzing the research groups according to the classification proposed by CAPES, it is possible to note that the highest percentage of research groups registered within the National Council for Scientific and Technological Development (CNPq) is in humanities (almost 19\%), followed by exact and earth science (nearly $17 \%$ ) and engineering (13\%). If we examine the distribution of Brazilian researchers by fields of knowledge, once again the biggest concentration is in humanities (19.56\%), followed by health sciences (17.97\%). The biggest concentration of article publications taking into account all Brazilian HEIs is in health science (24.69\%) and engineering accounts only for almost $9 \%$ of total publications in the country (table 5).

It is worth acknowledging that in Brazil there is a large allocation of human resources to humanities, applied social sciences and linguistics, arts and letters (which together account for almost $37 \%$ of researchers) and only $13 \%$ of researchers are allocated in engineering. Brazil may not be producing the quantity of relevant human resources required to compete in the world's hi-tech markets. This distortion towards humanities and applied social science in the distribution of researchers by area of knowledge may be directly related to the predominance of HEIs offering a number of course openings that demand little investment in equipment such as management, law and other human sciences (MELLO et al., 2009). The same conclusion can be made if the federally funded universities plus USP, UNESP and UNICAMP are analyzed: the number of researchers allocated in humanities, applied social sciences and linguistics, arts and letters account for almost $35 \%$ (figure 4). 
Table 5 - Distribution of research groups, researchers, articles, post-graduation Programs, post-graduation student, by fields of knowledge, all Brazilian HEIs, \%, 2008

\begin{tabular}{|c|c|c|c|c|c|c|}
\hline & $\begin{array}{c}\text { Research } \\
\text { Groups }\end{array}$ & Researchers & $\begin{array}{l}\text { Publication } \\
\text { of research } \\
\text { articles }\end{array}$ & $\begin{array}{l}\text { Technical } \\
\text { production }\end{array}$ & $\begin{array}{c}\text { Post- } \\
\text { graduation } \\
\text { programs* }\end{array}$ & $\begin{array}{c}\text { Post- } \\
\text { graduation } \\
\text { student** }\end{array}$ \\
\hline $\begin{array}{l}\text { Agricultural } \\
\text { Science }\end{array}$ & 9.55 & 10.37 & 15.72 & 4.02 & 10.98 & 9.44 \\
\hline $\begin{array}{l}\text { Biological } \\
\text { Science }\end{array}$ & 11.83 & 11.33 & 18.14 & 21.17 & 8.10 & 7.62 \\
\hline Health Science & 17.38 & 17.97 & 24.69 & 18.09 & 16.86 & 14.43 \\
\hline $\begin{array}{l}\text { Exact and Earth } \\
\text { Science }\end{array}$ & 11.03 & 10.03 & 13.23 & 18.62 & 10.09 & 9.63 \\
\hline Humanities & 18.51 & 19.56 & 10.05 & 3.98 & 14.25 & 16.99 \\
\hline $\begin{array}{l}\text { Applied Social } \\
\text { Science }\end{array}$ & 12.08 & 12.23 & 6.50 & 2.54 & 12.69 & 12.64 \\
\hline Engineering & 13.28 & 12.88 & 8.96 & 30.80 & 11.02 & 14.83 \\
\hline $\begin{array}{l}\text { Linguistics, Arts } \\
\text { and Literature }\end{array}$ & 6.35 & 5.63 & 2.70 & 0.78 & 5.41 & 6.45 \\
\hline Multidisciplinary & $\mathrm{n} / \mathrm{a}$ & $\mathrm{n} / \mathrm{a}$ & $\mathrm{n} / \mathrm{a}$ & $\mathrm{n} / \mathrm{a}$ & 10.59 & 7.98 \\
\hline Total & 100 & 100 & 100 & 100 & 100 & 100 \\
\hline
\end{tabular}

Source: Authors' own. Data sourced from the Directory of Research Groups of the National Council for Scientific and Technological Development (CNPq). *Data sourced from GeoCapes (Statistical Data from the Coordination of Improvement of Higher Education Personnel - CAPES). Note: Here we considered all public and private HEIs in Brazil. Note: Postgraduation programs refer to the number of master and doctoral programs. Bibliographic production refers to articles published in nationally and internationally indexed journals; technical production here refers to the sum of the production of software and technology products which had patent registration.

Figure 4 - Distribution of researchers by fields of knowledge, Brazilian federally funded universities and USP, UNESP and UNICAMP, 2008

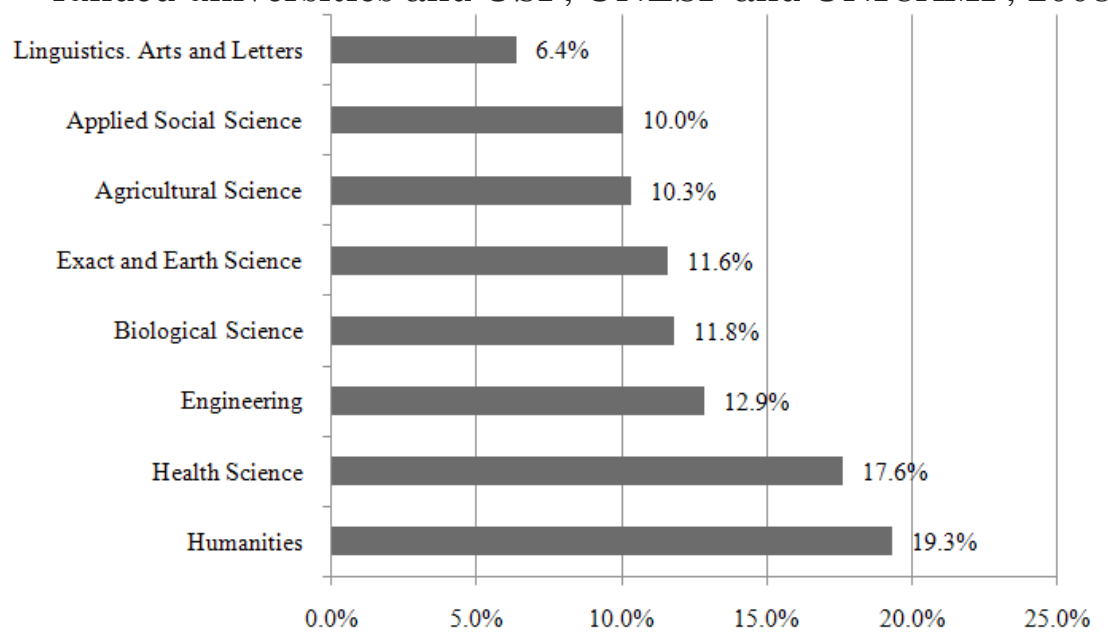

Source: Authors' own. Data sourced from the Directory of Research Groups of the National Council for Scientific and Technological Development (CNPq).

A peculiarity of the Brazilian tertiary education is that, as already mentioned in section 2, the public HEIs are the main supporter of the public system of research, especially thanks to the post-graduate programs sustained 
by those institutions. In 2008, the Coordination of Improvement of Higher Education Personnel (CAPES) had 2,718 registered programs that were offered in the country; humanities, applied social sciences and linguistics, arts and letters corresponded to nearly $32 \%$ of all programs. About 46.000 students were enrolled in post-graduate programs in the Brazilian HEIs in the same period: $36 \%$ of whom matriculated in humanities, applied social sciences and linguistics, arts and letters. Over the next few years the country will put in the market work force about 54 thousand Masters/Doctors from the aforementioned areas while only less than half of it will be made of engineers (Table 5).

It has been ascertained that not every type of research conducted by Brazilian HEIs is destined for strategic sectors defined by the industry and the country's development. We identify strategic sectors that can help the country's development taking the sectors defined by the Brazilian Industrial, Technological and Foreign Trade Policy (PITCE) as software, biotechnology, nanotechnology, biomass, capital goods, semiconductors and pharmaceuticals ${ }^{4}$. Accepting the aforementioned areas as strategic and 'leading to the future,' we propose that they have the potential radically to change processes/products, which is why there should be a better allocation of resources to these sectors. It is possible to cur across these sectors with the fields of knowledge proposed by CAPES referred before (Box 1). Although a direct correlation between fields of knowledge (CAPES) and strategic areas (PITCE) may be identified, nothing prevents research on a specific strategic area being conducted by researchers from other fields of knowledge. Chiarini and Vieira (in press) show that although 'software' belongs to Physical and Earth Sciences, there are researches related to software performed in other fields such as Agricultural, Engineering, Health Sciences, Social Sciences, Humanities, and even linguistics, Arts and Letters; the same may happen to other strategic sectors.

Box 1 - Fields of knowledge versus strategic sectors of PITCE

\begin{tabular}{ll}
\hline Fields of knowledge - CAPES & \multicolumn{1}{c}{ Strategic sectors - PITCE } \\
\hline Exact and Earth Sciences & Software \\
Engineering & Semiconductors, Capital goods \\
Health Sciences & Pharmaceuticals \\
Agricutural Sciences & Biomass \\
Life Sciences & - \\
Applied Social Sciences & - \\
Humanities & - \\
Linguistic, Arts and Letters & - \\
Multidisciplinary & Biotechnology, Nanotechnology \\
\hline
\end{tabular}

Source: Chiarini; Vieira, in press.

It is not the intention of this paper to suggest or to advocate the exclusion of research lines that do not fit the priority sectors of industrial and scientific and technological policies of the country. It is understood that they are important

\footnotetext{
4 The Industrial, Technological and Trade Policy (PITCE) was launched in 2004, under President Lula da Silva as a way of valuing innovation as a means of development, influenced by the evolutionary school. The PITCE recognizes that certain knowledge-intensive areas are 'future carrier' and strategic and therefore they should be encouraged, as a result of joint efforts. Thus, this policy aims to guide public action in pursuit of dynamic comparative advantages and productivity increase. (CAMPANARIO, et al., 2005).
} 
tools for understanding the regional, historical, cultural, economic and social dynamics (Chiarini; Vieira, in press). Nevertheless, we want to emphasize the importance that needs to be given to studies focused on the HEI priority areas for scientific development and technology as these are in line with the themes of Innovation Systems and is supported by the experience of countries that encouraged academic background in science and technology. This is the case in India which has stimulated the formation of qualified personnel in science and technology with emphasis on areas such as exact sciences and engineering.

\subsection{Public investments in the Brazilian HEIs}

Federal agencies like the Coordination of Improvement of Higher Education Personnel (CAPES) and the National Council for Scientific and Technological Development $(\mathrm{CNPq})$ in Brazil foster research through non-recoverable funds. State agencies have the same objective and the Research Support Foundation of São Paulo State (FAPESP) is by far the most important of them.

When we look at the non-recoverable funds granted by FAPESP, there was a real growth of $22.32 \%$, between 2006 and 2010. In 2010, FAPESP investments that supported researches in Brazilians HEIs located in São Paulo State amounted to US\$ 443.1 million and $11.06 \%$ of FAPESP resources to support research were directed to research in technological innovation. Considering CAPES investments, there was a real growth of $30.9 \%$, between 2006 and 2008. In 2008, this investment was US\$ 447.2 (Table 6)

Table 6 - Financial resources to research, CNPq, CAPES and
\begin{tabular}{lrrr}
\multicolumn{4}{c}{ FAPESP (2006-2010), U\$ million } \\
\hline 2006 & $\mathrm{CNPq}$ & CAPES & FAPESP \\
2007 & 408.6 & 260.3 & 239.8 \\
2008 & 617.5 & 308.7 & 282.1 \\
2009 & 635.7 & 447.2 & 347.7 \\
2010 & 665.2 & $\mathrm{n} / \mathrm{a}$ & 340.2 \\
$2006-2008$ Real growth & 900.0 & $\mathrm{n} / \mathrm{a}$ & 443.2 \\
$2006-2010$ Real growth & $46.02 \%$ & $30.9 \%$ & - \\
Source: Authors' own. Data sourced from CNPq, CAPES & $\mathrm{n} / \mathrm{a}$ & $22.32 \%$ \\
and FAPESP.
\end{tabular}
Note: To calculate the real growth we used the IPCA
inflation series from IPEAdata to deflate the R $\$$ values.

Between 2006 and 2010, there was a real growth of $46.02 \%$ of investments in research of CNPq in Brazilian HEIs. The distribution of resources for research in Brazilian HEIs shows that about only $10 \%$ of financing goes to areas of knowledge that have no relation to the strategic technological sectors of PITCE presented previously, as Humanities, Applied Social Sciences and Linguistics, Art and Letters. 
In 2008, Agronomy, Medicine, Engineering; Physics; Chemistry and Pharmaceuticals; and Computer Science received together 43,3\% of US $\$ 635.7$ million that $\mathrm{CNPq}$ invested in research projects, events and post graduate scholarships (in Brazil and abroad) (Figure 5).

Figure 5 - Distribution of investments in research per specific fields of knowledge,

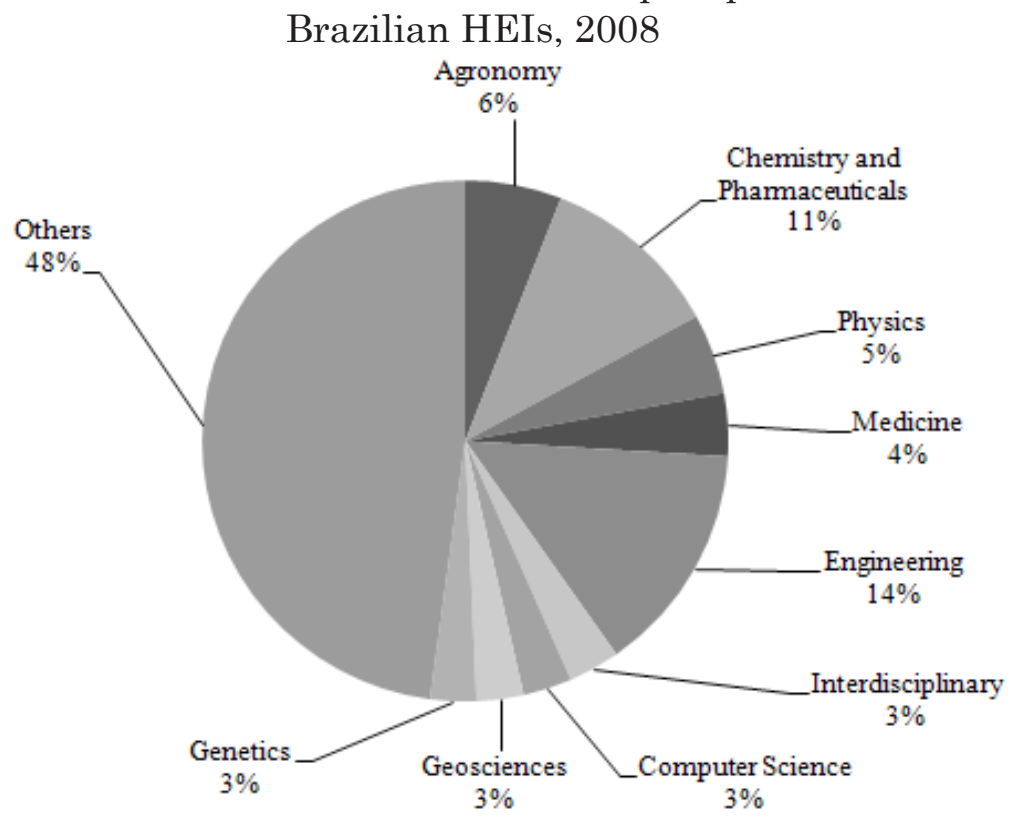

Source: Authors' own. Data sourced from the National Council for Scientific and Technological Development (CNPq).

These three agencies (Capes, FAPESP and CNPq) are very important in supporting Brazilian HEIs research and knowledge production. However, here we take into account only the investment of CNPq to support research projects. There are two reasons that justified this choice. The first is institutional: the choice of analyzing only this research supporter agency is because of its aim to promote and stimulate the scientific and technological development of the country and to contribute to the formulation of national science and technology policy and it is linked to the Ministry of Science and Technology. It is also recognized as the main source of non-recoverable fund for research as was identified in Table 6. The second reason is determined by our research in this paper: it is very difficult to find investment data on other institutions in research by HEIs, and this is true for all the other data investigated in this paper. Therefore we based our research on data sourced from CNPq.

In 2008, of the US $\$ 635.7$ million, CNPq invested US $\$ 195$ million only in research projects (of which $64 \%$ were placed in the federally funded universities plus USP, UNESP and UNICAMP.) Of this $64 \%, 14.09 \%$ was allocated to USP (figure 6). 
Figure 6 - Percentage of CNPq investment in research project, selected federally funded university plus USP, UNESP and UNICAMP, 2008

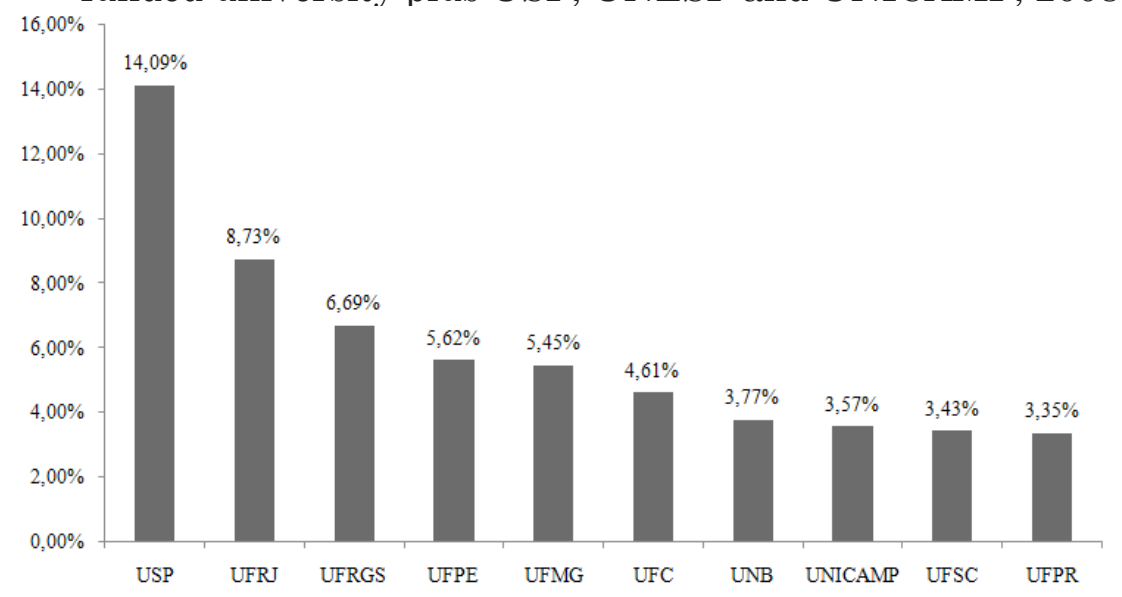

Source: Authors' own. Data sourced from the the National Council for Scientific and Technological Development (CNPq), Statistics on Science and Technology.

As opposed to what happens to the large amount of human resources allocated within humanities, applied social sciences and linguistics, arts and letters (together accounting for almost $37 \%$ of researchers, as was shown previously in section 3.2), Brazil seems to allocate financial resources more in Biological Science (21.7\%) and Engineering (15.2\%) which seems to align with the country's Industrial and Technological Policy (Table 7). Thus, if Brazil has a lag in innovation it may well cbe aused due to the lack of human resources in areas like engineering rather than from financing of research.

Table 7 - Distribution of Financing to Research per field of knowledge, 2008.

\begin{tabular}{lrr}
\hline & US\$ & $\%$ \\
\hline Biological Science & $42,428,019$ & 21.7 \\
Engineering & $29,775,138$ & 15.2 \\
Exact and Earth Science & $29,284,522$ & 15.0 \\
Agricultural Science & $29,261,384$ & 15.0 \\
Health Science & $28,622,003$ & 14.7 \\
Humanities & $9,682,300$ & 5.0 \\
Applied Social Science & $6,594,161$ & 3.4 \\
Linguistics. Arts and Literature & $1,382,026$ & 0.7 \\
Not available/not applicable/others & $18,262,863$ & 9.4 \\
\hline Total & 195.292 .416 & 100 \\
\hline
\end{tabular}

Source: Authors' own. Data sourced from the National Council for Scientific and Technological Development (CNPq), Statistics on Science and Technology.

\section{Conclusion: policy consideration}

The hypothesis of this paper was that Brazil was not appropriately allocating resources to produce new techno-scientific knowledge to compete in the world's technologically advanced markets in order to act on 'windows of opportunities' and that the country was not ready to act in an internationally 
competitive environment. Brazil seems to allocate financial resources more to biological sciences and engineering research which aligns with the country's Industrial and Technological Policy, however, it was demonstrated that not every type of research conducted by Brazilian HEIs was destined for strategic sectors. This was also true for the allocation of human resources in research.

In Brazil there is a large allocation of human resources within humanities, applied social sciences and linguistics, arts and letters (together accounting for almost 37\% of researchers) whereas only 13\% of researchers are allocated to engineering. Brazil may not be producing the quantity of relevant human resources required to compete in the world's hi-tech markets. This is very worrisome since the country needs qualified human capital in technological areas if it is to realize its goal of playing 'catch-up' with developed economies. Furthermore, training people in areas like health and education is also crucial in the Brazilian context, in order to meet needs that are both social and economical bottlenecks in the country.

The focus of the analysis was on federally funded universities and the three state funded universities of São Paulo because they are the main agents in producing knowledge in the Brazilian Innovation System. We demonstrated how the researchers are distributed in these institutions and also how productive each one of them is in terms of articles and technological production. From this, we could classify those institutions in three classes: 'leader universities' (formed only by USP), 'threshold universities' (which is constituted by UNESP, UNICAMP, UFRJ, UFRGS and UFMG) and the 'unveiling universities' which are clearly divided into two different subclasses: 'catching-up universities' (UFPE, UFSC, UFBA, UFF, UFPR and UNB) and 'embryonic universities' (the others).

The empirical findings presented suggest some normative actions: science and technology policies should make it possible for the country to enter a new pattern of industrial growth relying heavily on basic and applied research in the Brazilian universities. Thus, there should be a better coordination inducing scientific research to sectoral areas such as software, biotechnology, nanotechnology, biomass, capital goods, semiconductors and pharmaceuticals. This means that "research and development activities should be selective and clearly associated with broader processes of innovation based on the transfer, diffusion and absorption of technological competence" (Schwartzman, S., et al., 1995 , p. 33). The state's role in providing highly qualified human capital is crucial in Brazil. The public HEIs are the main supporter of the public system of research, especially thanks to the pos-graduation programs sustained by those institutions. 


\section{References}

Albuquerque, E. M. (2004). Science and technology systems in Less Developed countries: identifying a threshold level and focusing in the cases of India and Brazil. In: Moed. H.; Glänzel. W.; Schmoch. U. (Ed.). Handbook of quantitative science and technology research: the use of publication and patent statistics in studies of S\&T systems. Dordrecht: Kluwer Academic Publishers.

Albuquerque, E. M.; Silva; L. A.; Póvoa. L. M. C. (2005). Diferenciação intersetorial na interação entre empresas e universidades no Brasil. São Paulo em Perspectiva. São Paulo. v. 19. n. 1. p. 95-104.

Arocena, R.; Sutz, J. (2001). Changing knowledge production and Latin American universities. Research Policy. Vol. 30.

Campanário, M. A.; Silva, M. M.; Costa; T. R. (2005). Política Industrial, Tecnológica e de Comércio Exterior (PITCE): análise de fundamentos e arranjos institucionais. In: XI Seminário Latino-Iberoamericano de Gestión Tecnologica. Salvador.

Chiarini, T.; Vieira, K. P.. Alinhamento das atividades de pesquisa científica e tecnológica realizadas pelas IES federais de MG e as diretrizes da Política Industrial e de Comércio Exterior. Revista Brasileira de Inovação (Unicamp. Impresso). In press.

Etzkowitz, H.; Webster, A.; Gebhart, C.; Terra. B. (2000). The future of the university and the University of the future: the evolution of the ivory tower to entrepreneurial Paradigm. Research Policy. Vol. 29. No. 2.

Etzkowitz, H. (2003). Innovation in innovation: The Triple Helix of UniversityIndustry-government Relations. Social Science Information. Vol 42. No. 3.

Goldstein, H. A.; Drucker, J. (2007). Assessing the regional economic development impacts of universities: a review of current approaches. International Regional Science Review. 30. 1:20-24.

Leydesdorff, L. (2010). The Knowledge-Based Economy and the Triple Helix Model. Annual Review of Information Science and Technology. Blaise Cronin (Ed.); 44; 367-417.

Leydesdorff, L.; Etzkowitz, H. (1998). The triple helix as a model for innovation studies. Science \& Public Policy. Vol. 25. No 3.

Leydesdorff, L. (2000). The triple helix: an evolutionary model of innovations. Research Policy. Vol. 29.

Leydesdorff, L.; Meyer, M. (2006). The triple helix indicators of knowledge-based innovation systems: introduction to special issue. Research Policy. Vol. 35.

Maculan, A. M.; Mello, J. M. C. (2009). University start-ups for breaking lock-ins of the Brazilian economy. Science and Public Policy. Vol. 36. n. 2.

Marcovitch, J. (1999). A cooperação da universidade moderna com o setor empresarial. Revista de Administração. São Paulo. v. 34. n. 4. out./dez. 
Mello,J. M. C.; Maculan, A. M.; Renault, T. (2009). Brazilian Universities and their Contribution to Innovation and Development. In: Bo Goransson; Claes Brundenius. (Org.). Developing Universities: The Changing Role of Academic Institutions in Development. Londres: Routledge/IDRC. v 2009. p. 1-25.

Mowery, D.; Sampat, B. (2005). Universities in National Innovation Systems. In: Fagerberg. J.; Mowery. D.; Nelson. R. The Oxford Handbook of Innovation. Oxford: Oxford University Press.

Perez, C. (2001). Technological change and opportunities for development as a moving target. CEPAL Review. 75. dezembro 2001. pp. 109-130.

Rodrígues, A.; et al. (ed). (2008) Knowledge and innovation for competitiveness in Brazil. The International Bank for Reconstruction and Development/The World Bank. Washington. 268p.

RS, Royal Society. Knowledge. networks and nations: global scientific collaboration in the $21^{\text {st }}$ century. London: RS Policy document 03/2011.

Sabato, J. A.; Botana, N. (1968). La ciencia y la tecnología en el desarrollo futuro de América. Latina. Revista de la Integración. Buenos Aires. n. 3. p. 15-36.

Schwartzman, S. (1979). Formação da comunidade científica no Brasil. São Paulo: Nacional.

Schwartzman, S., et al. (1995). Science and technology in Brazil: a new policy for a global workd. In: Schwartzman, S. (org.). Science and technology in Brazil a new policy for a global world. São Paulo: Fundação Getúlio Vargas.

Suzigan, W.; Albuquerque, E. M. (2009). The underestimated role of universities for development: notes on historical roots of Brazilian system of innovation. In: XVth World Economic History Congress. 2009. Utrecht. XVth World Economic History Congress. Utrecht : International Economic History Association. 
Appendix 1 - List of the federally funded Universities of Brazil and the State funded Universities of São Paulo State,the Region where they are located, their abbreviation and their establishment year

\begin{tabular}{|c|c|c|c|}
\hline Region & Abbreviation & Universities & $\begin{array}{c}\text { Establishment } \\
\text { year }\end{array}$ \\
\hline \multirow[t]{5}{*}{ Center-West } & UFG & Universidade Federal de Goiás & 1960 \\
\hline & UFGD & Universidade Federal da Grande Dourados & 2005 \\
\hline & UFMS & Universidade Federal do Mato Grosso do Sul & 1979 \\
\hline & UFMT & Universidade Federal do Mato Grosso & 1970 \\
\hline & UNB & Universidade de Brasília & 1962 \\
\hline \multirow[t]{8}{*}{ North } & UFAC & Universidade Federal do Acre & 1974 \\
\hline & UFAM & Universidade Federal do Amazonas & 1962 \\
\hline & UFPA & Universidade Federal do Pará & 1957 \\
\hline & UFRA & Universidade Federal Rural da Amazônia & 2002 \\
\hline & UFRR & Universidade Federal de Roraima & 1985 \\
\hline & UFT & Universidade Federal de Tocantins & 2000 \\
\hline & UNIFAP & Universidade Federal do Amapá & 1987 \\
\hline & UNIR & Fundação Universidade Federal de Rondônia & 1982 \\
\hline \multirow[t]{15}{*}{ Northeast } & UFAL & Universidade Federal do Alagoas & 1961 \\
\hline & UFBA & Universidade Federal da Bahia & 1950 \\
\hline & UFC & Universidade Federal do Ceará & 1954 \\
\hline & UFCG & Universidade Federal de Campina Grande & 2002 \\
\hline & UFERSA & Universidade Federal Rural do Semi-Árido & 2005 \\
\hline & UFMA & Universidade Federal do Maranhão & 1966 \\
\hline & UFPB & Universidade Federal da Paraíba & 1960 \\
\hline & UFPE & Universidade Federal do Pernambuco & 1965 \\
\hline & UFPI & Universidade Federal do Piauí & 1968 \\
\hline & UFRB & Universidade Federal do Recôncavo Bahiano & 2006 \\
\hline & UFRN & Universidade Federal do Rio Grande do Norte & 1960 \\
\hline & UFRPE & Universidade Federal Rural do Pernambuco & 1955 \\
\hline & UFS & Universidade Federal de Sergipe & 1967 \\
\hline & UNILAB & Universidade da Integr. Inter. da Lusofonia Afro-Brasileira & 2010 \\
\hline & UNIVASF & Universidade Federal do Vale do São Francisco & 2002 \\
\hline \multirow[t]{11}{*}{ South } & FURG & Universidade Federal do Rio Grande & 1971 \\
\hline & UFCSPA & Universidade Federal de Ciências da Saúde de Porto Alegre & 1980 \\
\hline & UFFS & Universidade Federal da Fronteira Sul & 2009 \\
\hline & UFPEL & Universidade Federal de Pelotas & 1969 \\
\hline & UFPR & Universidade Federal do Paraná & 1950 \\
\hline & UFRGS & Universidade Federal do Rio Grande do Sul & 1950 \\
\hline & UFSC & Universidade Federal de Santa Catarina & 1959 \\
\hline & UFSM & Universidade Federal de Santa Maria & 1961 \\
\hline & UNILA & Universidade Federal da Integração Latino-Americana & 2010 \\
\hline & UNIPAMPA & Universidade Federal dos Pampas & 2008 \\
\hline & UTFPR & Universidade Tecnológica Federal do Paraná & 2005 \\
\hline \multirow[t]{22}{*}{ Southeast } & UFABC & Universidade Federal do ABC & 2005 \\
\hline & UFES & Universidade Federal do Espírito Santo & 1961 \\
\hline & UFF & Universidade Federal Fluminense & 1960 \\
\hline & UFJF & Universidade Federal de Juiz de Fora & 1960 \\
\hline & UFLA & Universidade Federal de Lavras & 1994 \\
\hline & UFMG & Universidade Federal de Minas Gerais & 1949 \\
\hline & UFOP & Universidade Federal de Ouro Preto & 1969 \\
\hline & UFRJ & Universidade Federal do Rio de Janeiro & 1920 \\
\hline & UFRRJ & Universidade Federal Rural do Rio de Janeiro & 1943 \\
\hline & UFSCAR & Universidade Federal de São Carlos & 1968 \\
\hline & UFSJ & Universidade Federal de São João del Rei & 2002 \\
\hline & UFTM & Universidade Federal do Triângulo Mineiro & 2005 \\
\hline & UFU & Universidade Federal de Uberlândia & 1978 \\
\hline & UFV & Universidade Federal de Viçosa & 1969 \\
\hline & UFVJM & Universidade Federal do Vale do Jequitinhonha e Mucurí & 2005 \\
\hline & UNIFAL/MG & Universidade Federal de Alfenas & 2002 \\
\hline & UNIFEI & Universidade Federal de Itajubá & 2002 \\
\hline & UNIFESP & Universidade Federal de São Paulo & 1994 \\
\hline & UNIRIO & Universidade Federal do Estado do Rio de Janeiro & 1979 \\
\hline & UNESP & Universidade Estadual Paulista* & 1976 \\
\hline & UNICAMP & Universidade Estadual de Campinas* & 1966 \\
\hline & USP & Universidade de São Paulo* & 1934 \\
\hline
\end{tabular}

Source: Brazilian Ministry of Education. (*)State funded universities of São Paulo State. 
Appendix 2 - Research groups, researchers, bibliographic production and technical production of the federally funded Universities of Brazil and the State funded Universities of São Paulo State, \%, 2008

\begin{tabular}{|c|c|c|c|c|}
\hline & Research Groups & Researchers & $\begin{array}{l}\text { Bibliographic } \\
\text { Production* }\end{array}$ & $\begin{array}{c}\text { Tecnical } \\
\text { Prodution** }\end{array}$ \\
\hline FURG & 0.87 & 0.79 & 0.70 & 0.83 \\
\hline UFABC & 0.09 & 0.07 & 0.10 & 0.25 \\
\hline UFAC & 0.26 & 0.33 & 0.15 & 0.06 \\
\hline UFAL & 1.58 & 1.35 & 0.38 & 0.52 \\
\hline UFAM & 1.34 & 1.62 & 0.54 & 0.80 \\
\hline UFBA & 3.06 & 3.43 & 1.65 & 1.69 \\
\hline UFC & 1.93 & 2.01 & 2.08 & 1.66 \\
\hline UFCG & 0.96 & 1.05 & 1.61 & 0.46 \\
\hline UFCSPA & 0.21 & 0.20 & 0.40 & 0.03 \\
\hline UFERSA & 0.20 & 0.21 & 0.46 & 0.06 \\
\hline UFES & 1.71 & 1.34 & 0.63 & 0.74 \\
\hline UFF & 2.89 & 2.78 & 1.62 & 1.05 \\
\hline UFG & 1.71 & 1.99 & 1.94 & 1.60 \\
\hline UFGD & 0.41 & 0.42 & 0.94 & 0.28 \\
\hline UFJF & 1.20 & 1.12 & 0.54 & 0.74 \\
\hline UFLA & 0.52 & 0.70 & 1.40 & 1.54 \\
\hline UFMA & 0.84 & 0.87 & 0.61 & 0.03 \\
\hline UFMG & 4.74 & 4.81 & 2.71 & 9.23 \\
\hline UFMS & 1.48 & 1.26 & 3.11 & 0.46 \\
\hline UFMT & 1.54 & 1.44 & 0.85 & 0.52 \\
\hline UFOP & 0.50 & 0.47 & 0.41 & 0.40 \\
\hline UFPA & 1.72 & 1.72 & 0.68 & 0.83 \\
\hline UFPB & 1.83 & 1.87 & 1.49 & 1.38 \\
\hline UFPE & 3.49 & 3.29 & 2.10 & 2.28 \\
\hline UFPEL & 1.12 & 1.17 & 2.19 & 0.89 \\
\hline UFPI & 0.96 & 0.88 & 0.86 & 0.34 \\
\hline UFPR & 2.80 & 3.09 & 1.93 & 3.60 \\
\hline UFRA & 0.16 & 0.21 & 1.52 & 0.00 \\
\hline UFRB & 0.24 & 0.31 & 0.22 & 0.37 \\
\hline UFRGS & 4.71 & 4.77 & 3.02 & 4.00 \\
\hline UFRJ & 6.19 & 5.67 & 5.65 & 7.66 \\
\hline UFRN & 1.18 & 1.47 & 1.19 & 1.14 \\
\hline UFRPE & 0.58 & 0.79 & 0.96 & 0.28 \\
\hline UFRR & 0.39 & 0.34 & 0.42 & 0.06 \\
\hline UFRRJ & 0.96 & 0.95 & 0.64 & 0.46 \\
\hline UFS & 0.91 & 0.97 & 0.77 & 0.37 \\
\hline UFSC & 3.18 & 3.31 & 2.09 & 4.31 \\
\hline UFSCAR & 2.24 & 1.84 & 2.41 & 1.91 \\
\hline UFSJ & 0.41 & 0.37 & 1.39 & 0.25 \\
\hline UFSM & 1.88 & 1.62 & 1.47 & 0.98 \\
\hline UFT & 0.69 & 0.64 & 1.05 & 0.03 \\
\hline UFTM & 0.26 & 0.24 & 0.21 & 0.00 \\
\hline UFU & 1.43 & 1.37 & 0.95 & 2.00 \\
\hline UFV & 1.75 & 1.71 & 2.72 & 5.84 \\
\hline UFVJM & 0.40 & 0.28 & 1.15 & 0.18 \\
\hline UNB & 2.36 & 2.84 & 2.28 & 3.17 \\
\hline UNIFAL/MG & 0.19 & 0.21 & 0.15 & 0.22 \\
\hline UNIFAP & 0.02 & 0.15 & 0.05 & 0.06 \\
\hline UNIFEI & 0.32 & 0.30 & 0.14 & 0.52 \\
\hline UNIFESP & 2.03 & 1.74 & 3.13 & 1.81 \\
\hline UNIPAMPA & 0.12 & 0.14 & 0.11 & 0.06 \\
\hline UNIR & 0.32 & 0.42 & 0.12 & 0.15 \\
\hline UNIRIO & 0.62 & 0.63 & 0.39 & 0.09 \\
\hline UNIVASF & 0.26 & 0.22 & 0.15 & 0.12 \\
\hline UTFPR & 1.07 & 1.04 & 0.47 & 0.92 \\
\hline UNESP & 6.02 & 6.08 & 8.45 & 4.71 \\
\hline UNICAMP & 5.32 & 5.36 & 6.60 & 9.44 \\
\hline USP & 13.84 & 13.78 & 18.02 & 16.61 \\
\hline Total (\%) & 100.00 & 100.00 & 100.00 & 100.00 \\
\hline Total (absolute value) & 13,282 & 71,074 & 477,806 & 3,251 \\
\hline \multicolumn{5}{|c|}{$\begin{array}{l}\text { Source: Authors' own. Data sourced from the Directory of Research Groups of } \\
\text { the National Council for Scientific and Technological Development (CNPq). }\left(^{*}\right) \\
\text { Articles published in nationally and internationally indexed journals; (**) Technical } \\
\text { Production here refers to the sum of the production of software and technology } \\
\text { products which had patent registration. }\end{array}$} \\
\hline
\end{tabular}


